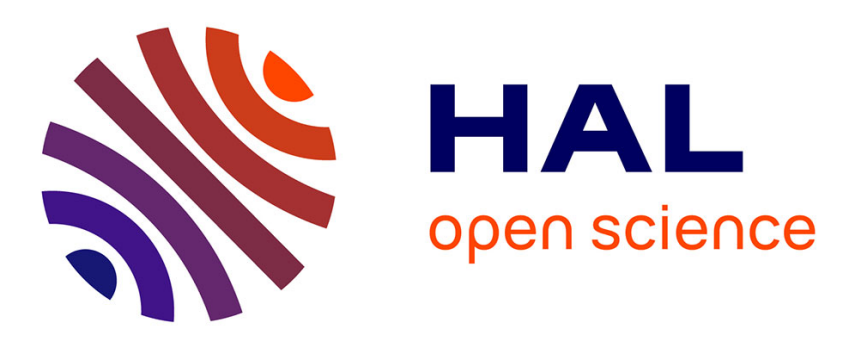

\title{
PD-L1 inhibitor-induced worsening of eosinophilic obstructive lung disease successfully rescued with anti-interleukin 5 receptor (IL-5R) therapy
}

Flora Wassmer, Carey Suehs, Clement Boissin, Arnaud Bourdin, Jérémy

Charriot

\section{To cite this version:}

Flora Wassmer, Carey Suehs, Clement Boissin, Arnaud Bourdin, Jérémy Charriot. PD-L1 inhibitorinduced worsening of eosinophilic obstructive lung disease successfully rescued with anti-interleukin 5 receptor (IL-5R) therapy. Journal of Allergy and Clinical Immunology: In Practice, 2020, 9 (1), pp.567-569. 10.1016/j.jaip.2020.08.022 . hal-02922639

\section{HAL Id: hal-02922639 \\ https://hal.science/hal-02922639}

Submitted on 6 Aug 2021

HAL is a multi-disciplinary open access archive for the deposit and dissemination of scientific research documents, whether they are published or not. The documents may come from teaching and research institutions in France or abroad, or from public or private research centers.
L'archive ouverte pluridisciplinaire HAL, est destinée au dépôt et à la diffusion de documents scientifiques de niveau recherche, publiés ou non, émanant des établissements d'enseignement et de recherche français ou étrangers, des laboratoires publics ou privés. 


\section{PD-L1 inhibitor-induced worsening of eosinophilic obstructive lung disease successfully rescued with anti- interleukin 5 receptor (IL-5R) therapy}

Flora Wassmer, $\mathrm{MD}^{\mathrm{a}}$, Carey Suehs, $\mathrm{PhD}^{\mathrm{a}, \mathrm{b}}$,

Clement Boissin, $\mathrm{MD}^{\mathrm{a}}$, Arnaud Bourdin, $\mathrm{MD}, \mathrm{PhD}^{\mathrm{a}, \mathrm{c}}$, and Jeremy Charriot, $\mathrm{MD}^{\mathrm{a}, \mathrm{c}}$

\section{Clinical Implications}

- Programmed death ligand-1 pathway blockade therapy may disrupt control of a pre-existing obstructive lung disease. In this kind of situation, concomitant anti-IL-5 receptor therapy remains safe and effective.

Biologics positively transformed the world of asthma. ${ }^{1-3}$ Benralizumab, a monoclonal antibody that binds to the IL-5 receptor (IL-5R), induces sustained eosinophil depletion and improvement of asthma control. ${ }^{2}$ Surprisingly, this benefit could not be reproduced in chronic obstructive pulmonary disease (COPD) despite the choice of blood eosinophil count as an inclusion criterion. ${ }^{4}$ Whether asthmatics who smoke fit in these complex clinical situations is one aspect of the asthma-COPD overlap (ACO) debate.

In tandem, the oncology field has also considerably evolved with the development of programmed death ligand-1 (PD-L1) and programmed death-1 (PD-1) pathway therapies. Durvalumab is a monoclonal antibody that blocks PD-L1 binding with PD-1 and CD80, thus allowing T cells to recognize and then kill tumor cells overexpressing PD-1. ${ }^{5}$ Despite close relationships between obstructive lung diseases, smoking, and lung cancer, little is known about the interactions between PD-1/PDL-1 signaling pathways and these diseases, especially in regard to airway inflammation and hyperresponsiveness (AHR). Here, we present the case of a patient with purported ACO consecutively treated with durvalumab for lung adenocarcinoma and then with benralizumab for subsequently worsening eosinophilic obstructive lung disease.

A 71-year-old man with a medical history of allergic rhinitis, hypertension, and type 2 diabetes initially presented in July 2017 at our respiratory department for an acute dyspnea episode associated with wheezing, cough, and sputum. The patient had multiple known sensitizations (dust mites, cat, dog). He reported a family history of asthma, active smoking ( 5 cigarettes per day, 55 pack-years), and no occupational exposure. He described similar recurrent wheezing episodes since childhood but no hospitalization before this. He did not receive any systemic steroids or antibiotics in the past 5 years. Regarding this episode, no evident trigger was found (microbiology and virology were both negative). Initial forced expiratory volume in 1 second $\left(\mathrm{FEV}_{1}\right)$ was measured at $1040 \mathrm{~mL}(35 \%$ of the predicted value) and gained $13 \%(120 \mathrm{~mL})$ after bronchodilatation. Chest highresolution computed tomography $(\mathrm{CT})$ revealed predominantly upper lobe emphysema and bronchial wall thickening. Clinical and paraclinical features are summarized in Table I and Figure 1. In this case of severe nonreversible obstructive airflow, smoking history, and emphysema, a dual inhaled bronchodilator with a long-acting $\beta$-agonist and a long-acting muscarinic agonist was first introduced. During follow-up, significant seasonal variability of symptoms and $\mathrm{FEV}_{1}$ (from 720 to $1180 \mathrm{~mL}, 25 \%$ to $40 \%$ of predicted value) were noted, with hospitalizations for exacerbations always occurring during the same period (July 2017, 2018, and 2019). Blood eosinophilia ranged from 320 to $390 / \mathrm{mm}^{3}$. Despite smoking cessation, allergen avoidance, and antihistamine therapy, severe exacerbations became increasingly frequent and systematically required short courses of oral steroids to achieve prompt clinical improvement. These elements favored the diagnosis of ACO. Inhaled corticosteroids were promptly added (budesonide $1600 \mathrm{mg}$ daily), and then azithromycin $250 \mathrm{mg} /$ day was introduced in July 2018. The latter failed to reduce the patient's exacerbation rate and was stopped after 6 months. Finally, a daily dose of $10 \mathrm{mg}$ of prednisolone was required to gain and maintain control.

In October 2018, a spiculated nodule of $18 \mathrm{~mm}$ in the right upper lobe, along with 2 other homolateral nodules, was discovered on a chest CT scan. Endobronchial ultrasoundguided node aspiration confirmed the diagnosis of lung adenocarcinoma (T4 N2 M0). The PD-1 expression of tumor cells was 5\%. Concomitant radiotherapy and 6 cycles of chemotherapy (paclitaxel and carboplatin) were administered before durvalumab was introduced in June 2019, given the partial response observed at 6 months. Whereas only 1 mild exacerbation occurred during chemotherapy, from the start of durvalumab, we observed a worsening of asthma control with 3 exacerbations ( 2 of which were severe) occurring in a 2 -month period of treatment. Each exacerbation required an increasingly stronger dosage regimen of oral steroids, with a novel minimum effective dose of $20 \mathrm{mg}$ of prednisolone between exacerbations. A new CT-scan ruled out PD-L1 inhibitor-induced interstitial lung disease.

A multidisciplinary consensus decided to start an anti-IL-5R therapy (benralizumab) in September 2019. A dramatic clinical improvement with combined immunotherapy (durvalumabbenralizumab) was observed, namely no exacerbations and a significant improvement in Asthma Control Test scores. FEV 1 remained unchanged (Table I). Oral corticosteroid tapering is still ongoing with a current dosage regimen of $5 \mathrm{mg} /$ day of prednisolone concomitantly with a tapering of inhaled corticosteroids. To date, lung cancer remains stable and no side effects induced by this combination immunotherapy were noticed.

We here report the first observation of obstructive lung disease worsening induced by durvalumab and then rescued with antiIL5R therapy.

Previously published preliminary observations suggest that a PD-1 pathway blockade does not worsen obstructive lung diseases such as asthma or COPD in terms of symptoms, lung function, or exacerbations. Side effects reported in "real-life studies" of these molecules in these patients are quite consistent. ${ }^{6}$ However, PD-1 is an important negative regulator of $\mathrm{KLRG}^{+}$ ILC2 subsets in both mice and humans. PD-1 is exclusively expressed by ILC2s, and disrupting PD-1 signaling either by 
TABLE I. Clinical evolution of obstructive lung disease according to treatment

\begin{tabular}{|c|c|c|c|c|c|c|c|}
\hline & July 2017 & July 2018 & March 2019 & June 2019* & September 2019 & December 2019 & February 2020 \\
\hline$\overline{\text { mMRC dyspnea scale }}$ & 1 & 2 & 2 & 4 & 4 & 1 & 1 \\
\hline ACT & 14 & 16 & 13 & 5 & 10 & 24 & 20 \\
\hline $\mathrm{FEV}_{1}(\mathrm{~mL})$ & 1040 & & 720 & & & & 720 \\
\hline Blood eosinophils $\left(/ \mathrm{mm}^{3}\right)$ & & 390 & 320 & 140 & 150 & 0 & 0 \\
\hline Prednisolone $(\mathrm{mg} / \mathrm{d})$ & 0 & 0 & 0 & 80 & 20 & 10 & 5 \\
\hline ICS (BUD $\mu \mathrm{g} / \mathrm{d})$ & 0 & 800 & 800 & 1600 & 1600 & 800 & 400 \\
\hline
\end{tabular}

$A C T$, Asthma Control Test; BUD, Budesonide; FEVI, Forced Expiratory Volume in 1 second; ICS. Inhaled Corticosteroids

*Durvalumab introduced.

$\dagger$ Benralizumab introduced.

$\ddagger$ Modified Medical Research Council Dyspnea Scale: $0=$ dyspnea only with strenuous exercise; $1=$ dyspnea when hurrying or walking up a slight hill; $2=$ walks slower than people of the same age because of dyspnea or has to stop for breath when walking at own pace; $3=$ stops for breath after walking 100 yards or after a few minutes; $4=$ too dyspneic to leave house or breathless when dressing.

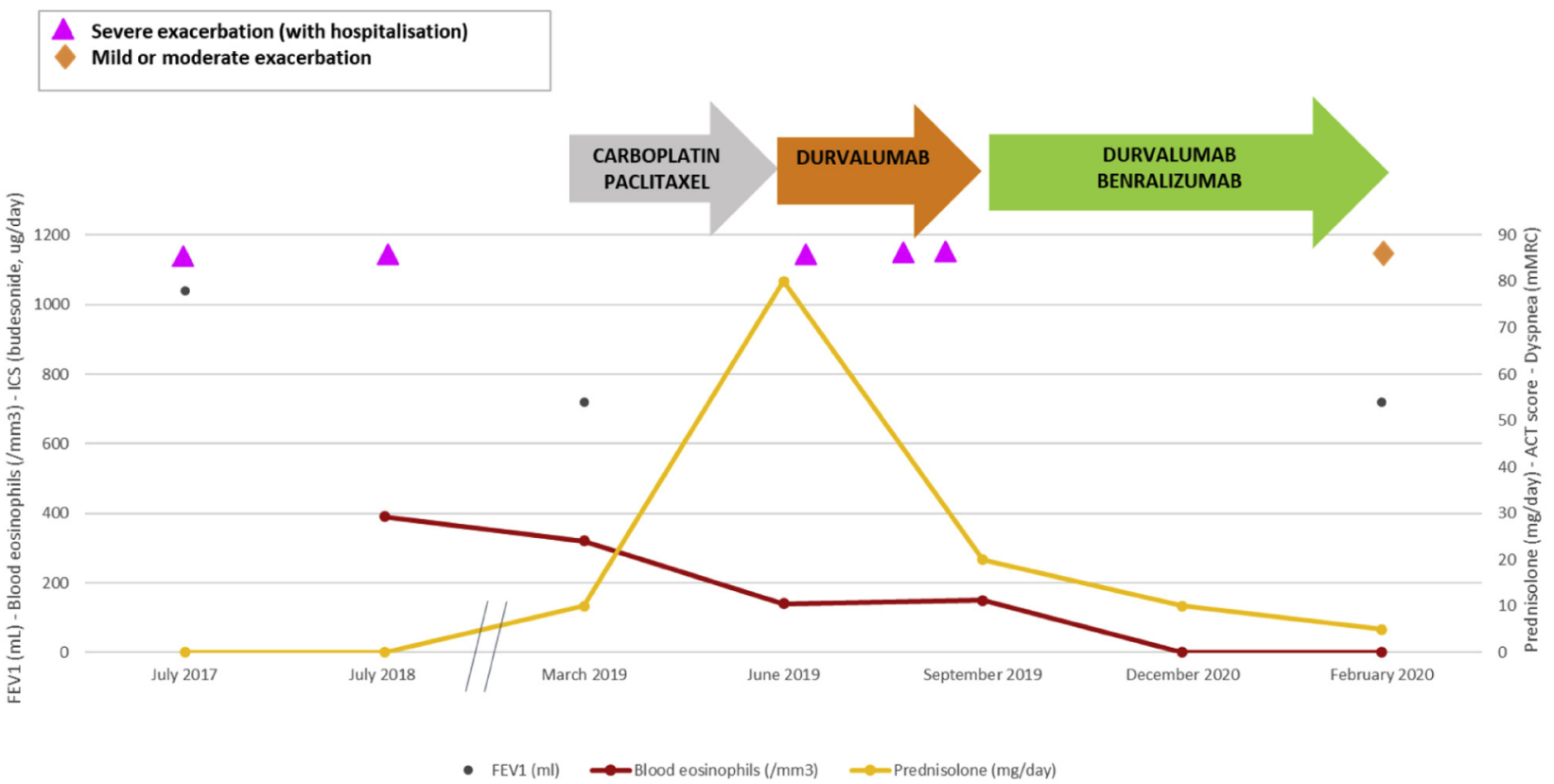

FIGURE 1. Evolution of blood eosinophils according to treatment.

genetic deletion or by antibody blockade significantly enhances KLRG1 ${ }^{+}$ILC2 cells in both number and function. Specifically, the target function relevant to this case report is the production of IL-13 in the lungs, which plays a major role in the pathophysiology of asthma.

McGee et $\mathrm{al}^{8}$ showed that immune checkpoint inhibitors targeting PD-1 could reverse AHR and reduce inflammation through interaction with Tregs from lung tissue in mice. This effect was counter-balanced with the administration of an anti-PD-1. ${ }^{8}$

Nevertheless, studies assessing the PD-1 family embers in asthma have also shown conflicting results. For instance, a mouse model of allergic asthma showed that blocking PD-1/PDL-1 improved AHR, not through the alteration of the magnitude of the T2 immune response, but actually through the development of a concomitant Th17 immune response.

PD-L1 pathway blockade therapy for lung cancer may disrupt control of a pre-existing obstructive lung disease; this can be rescued with concomitant anti-IL-5R as an add-on therapy. More attention to $\mathrm{PD}-1 / \mathrm{PD}-\mathrm{L} 1$ pathway therapy safety is required in regard to our observation, keeping in mind that biologics may remain safe and efficient in such cases.

${ }^{a}$ Department of Respiratory Diseases, University of Montpellier, CHU Montpellier, Montpellier, France

${ }^{b}$ Department of Medical Information, University of Montpellier, CHU Montpellier, Montpellier, France

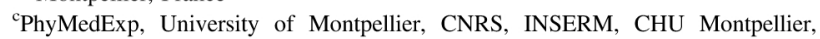
Montpellier, France

No funding was received for this work.

Conflicts of interest: C. Suehs reports a grant from AstraZeneca. A. Bourdin reports grants, personal fees, nonfinancial support, and other from AstraZeneca, Boehringer Ingelheim, GlaxoSmithKline, and Actelion; personal fees, nonfinancial support, and other from Novartis, Regeneron, and Chiesi Pharmaceuticals; personal fees and nonfinancial support from Teva; personal fees from Gilead; nonfinancial support and other from Roche; and other from Nuvaira, from null, outside the submitted work. The rest of the authors declare that they have no relevant conflicts of interest.

Received for publication June 12, 2020; revised August 10, 2020; accepted for publication August 10, 2020.

Available online August 22, 2020. 
Corresponding author: Jeremy Charriot, MD, CHU Montpellier, Hôpital Arnaud de Villeneuve, 371. Av. du doyen Gaston Giraud, 34295 Montpellier Cedex, France. E-mail: i-charriot@chu-montpellier.fr.

\section{REFERENCES}

1. Ortega HG, Liu MC, Pavord ID, Brusselle GG, FitzGerald JM, Chetta A, et al. Mepolizumab treatment in patients with severe eosinophilic asthma. N Engl J Med 2014;371:1198-207.

2. Bleecker ER, FitzGerald JM, Chanez P, Papi A, Weinstein SF, Barker P, et al. Efficacy and safety of benralizumab for patients with severe asthma uncontrolled with high-dosage inhaled corticosteroids and long-acting $\beta 2$-agonists (SIROCCO): a randomised, multicentre, placebo-controlled phase 3 trial. Lancet Lond Engl 2016;388:2115-27.

3. Castro M, Corren J, Pavord ID, Maspero J, Wenzel S, Rabe KF, et al. Dupilumab efficacy and safety in moderate-to-severe uncontrolled asthma. N Engl J Med 2018;378:2486-96.
4. Criner GJ, Celli BR, Brightling CE, Agusti A, Papi A, Singh D, et al. Benralizumab for the prevention of COPD exacerbations. N Engl J Med 2019;381: 1023-34.

5. Ohaegbulam KC, Assal A, Lazar-Molnar E, Yao Y, Zang X. Human cancer immunotherapy with antibodies to the PD-1 and PD-L1 pathway. Trends Mol Med 2015;21:24-33.

6. Hui R, Özgüroğlu M, Villegas A, Daniel D, Vicente D, Murakami S, et al. Patient-reported outcomes with durvalumab after chemoradiotherapy in stage III, unresectable non-small-cell lung cancer (PACIFIC): a randomised, controlled, phase 3 study. Lancet Oncol 2019;20:1670-80.

7. Taylor S, Huang Y, Mallett G, Stathopoulou C, Felizardo TC, Sun M-A, et al. PD-1 regulates KLRG1+ group 2 innate 1ymphoid cells. J Exp Med 2017;214: 1663-78.

8. McGee HS, Yagita H, Shao Z, Agrawal DK. Programmed death-1 antibody blocks therapeutic effects of T-regulatory cells in cockroach antigen-induced allergic asthma. Am J Respir Cell Mol Biol 2010;43:432-42.

9. McAlees JW, Lajoie S, Dienger K, Sproles AA, Richgels PK, Yang Y, et al. Differential control of CD4(+) T-cell subsets by the PD-1/PD-L1 axis in a mouse model of allergic asthma. Eur J Immunol 2015;45:1019-29. 